\title{
Effect of variety and planting date of rice on population of natural enemies of brown planthopper, Nilaparvata lugens (Stal)
}

\author{
A. S. Tetarwal*, Lakhi Ram, Ram Singh and Manoj Kumar Jat \\ Department of Entomology, Choudhary Charan Singh Haryana Agricultural University, Hisar - 125004 (Haryana), \\ INDIA \\ *Corresponding author. E-mail: astetarwal@gmail.com
}

Received: June, 25 2014; Revised received: August 22, 2014 ; Accepted: October 01, 2014

\begin{abstract}
The present study on the effect of variety and planting date of rice on population of natural enemies of brown planthopper, Nilaparvata lugens (Stal) showed that during August, the mean population of spiders was statistically on par on CSR 30 and PR 114. The population differed with dates and was significantly $(p=0.05)$ higher (9.0/10 hills) in $D_{2}$ during 2011 only. There was no significant difference in the population of spiders on two varieties and dates of transplanting during September 2011 only. However, significantly higher population of spiders was recorded in variety PR 114 (21.65/10 hills) and $D_{2}$ (20.52/10 hills) than on CSR 30 (13.67/10 hills) and $D_{1}(14.80 / 10$ hills) during September, 2012. The mean population of spiders did not differ significantly with the dates during October, 2011 and 2012. However, it was significantly higher on variety PR 114 (27.65/10 hills) than on CSR 30 during both the crop seasons. Mirid bugs did not appear in the month of August, 2011 and 2012 whereas during September 2011, the variety CSR 30 and $D_{1}$ registered significantly higher population than other variety and date. However, a reverse trend was observed with varieties and dates during 2012. The mean population of coccinelid, carabid and staphylinid beetles remained very low on both the varieties in the month of August during 2011 and 2012. However, the population of these predators was influenced significantly by the varieties and dates during 2012. The population of nymphal-adult parasitoids also remained very low during both years and was not influenced by varieties and dates.
\end{abstract}

Keywords: Coccinelids, Mirid bugs, Nymphal-adult, Planting dates, Population dynamics, Spiders.

\section{INTRODUCTION}

Rice (Oryza sativa L.) is the world most important crop and a staple food for more than half of the world's population. Worldwide, rice is grown on 161 million hectares, with an annual production of 678.7 million tonnes of paddy. About 90 per cent of the world's rice is grown and produced (143 million hectares of area with a production of 612 million tonnes of paddy) in Asia (FAO, 2009). It is grown on an area of 43.97 million hectare in the country with total production of 104.32 million tonnes and productivity of $2372 \mathrm{~kg} \mathrm{ha}{ }^{-1}$. However, Haryana occupied an area of 1.24 million hectare with total production of 3.76 million tonnes during 2011-12 (Anonymous, 2012).

Rice is cultivated in varied environment like uplands, deep water, shallow lowlands and irrigated conditions. However, the most preferred ecology of rice plant is tropical and humid climate with temperature ranges of $15-35{ }^{0} \mathrm{C}$ and relative humidity of $85-100$ percents. This climate is also suitable for development and multiplication of many insects. There are more than 100 insect species recorded as feeding on rice plant. About 20-25 of them reached the status of pest causing economic losses under farmer's field situations. Among them, stem borers, plant hoppers, leafhoppers, leaf folder, gall midge, rice hispa, gundhi bug, case worm, armyworm, cut worm and rice thrips are the most important in India and other countries (Krishnaiah et al., 2008). Singh and Dhaliwal (1994) reported that the overall yield loss due to these insect pests varies between 21-51 per-cents.

In Haryana, plant hoppers, leaf folder, stem borer, rice hispa, gundhi bug and army worm are some important insect pests. Among the plant hoppers, two plant hoppers of economic importance are the brown plant hopper (BPH), Nilaparvata lugens (Stal) and white backed plant hopper (WBPH), Sogatella furcifera (Horvath) of the family Delphacidae. The severe outbreaks of BPH occurred in Haryana in 2008 and 2010 (Anonymous, 2008 and 2010). BPH damages plants directly by sucking the sap and by ovipositing in plant tissues, causing plant wilting and 'hopperburn'. This insect has a high reproductive potential to multiply ten to hundred fold in each generation. Kenmore et al. (1984) submitted that due to the widespread misuse of insecticides, natural enemies were killed which lead to the outbreaks of BPH. Promiscuous use of insecticides also promotes ISSN : 0974-9411 (Print), 2231-5209 (Online) All Rights Reserved @ Applied and Natural Science Foundation www.ansfoundation.org 
resurgence of the insect pest (Heinrichs and Mochida, 1984). The BPH food web is simple and plays an important role in regulating the population. It has only 76 taxa represented by 11 parasitoids, 11 secondary natural enemies and rest is predators dominated by 50 species of spiders $(65.8 \%$ of total taxa in the web). It is presumed that spiders must have played a major regulatory function against plant hoppers (Dupo and Barrion, 2009). Claridge et al. (1999) reported that parasitism by species of Oligosita (Hymenoptera: Trichogrammatidae) and Anagrus spp. (Hymenoptera: Mymaridae) varied between 18 and 61 per-cent in the dry, and from 1 to 65 per-cent in the wet seasons. The predators of BPH (spiders, mirid bug and carabids) were also observed throughout the study period (Prashant et al., 2012). One of the major factors contributing to the increase in severity of this insect is the indiscriminate use of insecticides, which also kill many natural enemies. Further, insecticides residues in Basmati are a big issue at national and international levels now a days. Therefore, to avoid catastrophe, the aim of the present work was to develop an integrated pest management approach for BPH control.

\section{MATERIALS AND METHODS}

The experiment to study the population dynamics natural enemies of brown plant hopper in relation to variety and transplanting date consisted of two rice varieties viz. CSR 30 (tall scented/Basmati) and PR 114 (semidwarf non-scented) and two dates of transplanting viz. last week of June $\left(25^{\text {th }}\right.$ June during 2011 and $27^{\text {th }}$ June during 2012) and first week of July ( $5^{\text {th }}$ July during 2011 and $7^{\text {th }}$ July during 2012) denoted here as $D_{1}$ and $\mathrm{D}_{2}$, respectively. The crop (30 days old seedlings) was transplanted in puddled field at $20 \times 15 \mathrm{~cm}$ spacing on plots of size $10 \times 7.5 \mathrm{~m}$. The treatments were arranged in factorial randomized block design with 5 replications. The recommended agronomic practices were followed to raise the crop. However, no pesticide was applied till the harvest of the crop.

The number of different post embryonic development stages of the brown plant hopper natural enemies were collected from 10 hills selected randomly from each plot at weekly intervals. The first observation was taken 15 days after transplanting (DAT) and continued till harvesting. The population of $\mathrm{BPH}$ along with predators was recorded in the forenoon by taping the plant by hand from the base of the plant to the top in to a $30 \times 22.5 \times 5 \mathrm{~cm}$ white enamel tray containing a little water. The plant hopper along with natural enemies were counted and recorded. The tray was cleaned every time before next observation.

\section{RESULTS}

Population dynamics of spiders during August, 2011 and 2012: The differences in population of spiders on varieties CSR 30 and PR 114 did not differ significantly during both years but significantly $(\mathrm{p}=0.05)$ higher population of spiders was recorded in $\mathrm{D}_{2}$ during the year 2011 only. The mean number of spiders was 7.65 and $8.02 / 10$ hills and 4.57 and 4.42 spiders/10 hills during 2011 and 2012, respectively. The mean maximum population of spiders $(9.00 / 10$ hills) was significantly $(\mathrm{p}=0.05)$ higher in $\mathrm{D}_{2}$ than 6.67 spiders/10 hills in $\mathrm{D}_{1}$ during 2011 (Table 1).

Population dynamics of spiders during September, 2011 and 2012: In September, there was no significant difference in the population of spiders in both the varieties and dates of transplanting during 2011 only. However, during 2012, significantly higher population of spiders (21.65/10 hills) was recorded in variety PR 114 than 13.67/10 hills in CSR 30. The number of spiders (20.52 spiders/10 hills) was significantly $(\mathrm{p}=0.05)$ higher in $D_{2}$ than 14.80 spiders/10 hills in $D_{1}$. The interaction between variety and date was significant ( $\mathrm{p}=0.05$ ) during 2011 only. The higher population of spiders $\left(16.28 / 10\right.$ hills) was recorded in $D_{1}$ than the 12.44 spiders/10 hills in $\mathrm{D}_{2}$ but in variety PR 114 , the number of spiders (16.56/10 hills) was significantly higher in $\mathrm{D}_{2}$ than 12.28 spiders/10 hills in $\mathrm{D}_{1}$ (Table 2). Population dynamics of spiders during October, 2011 and 2012: Data presented in table 3 showed that the mean population of spiders did not differ significantly in both the dates during 2011 and 2012 . However, it was significantly $(\mathrm{p}=0.05)$ higher on variety PR 114 than in CSR 30 during both crop

Table 1. Population dynamics of spiders during August, 2011 and 2012.

\begin{tabular}{|c|c|c|c|c|c|c|}
\hline \multicolumn{7}{|c|}{ Monthly mean population of spiders / 10 hills } \\
\hline \multirow{3}{*}{ Varieties } & \multicolumn{3}{|c|}{2011} & \multicolumn{3}{|c|}{2012} \\
\hline & \multicolumn{2}{|c|}{ Dates of transplanting } & \multirow[t]{2}{*}{ Mean } & \multicolumn{2}{|c|}{ Dates of transplanting } & \multirow[t]{2}{*}{ Mean } \\
\hline & D1 & D2 & & D1 & D2 & \\
\hline CSR 30 & 5.95 & 9.35 & 7.65 & 4.95 & 4.20 & 4.57 \\
\hline PR 114 & 7.40 & 8.65 & 8.02 & 4.30 & 4.55 & 4.42 \\
\hline \multirow[t]{2}{*}{ Mean } & 6.67 & 9.00 & & 4.62 & 4.37 & \\
\hline & Variety & Date & Variety $\times$ Date & Variety & Date & Variety $\times$ Date \\
\hline $\mathrm{SE}(\mathrm{m})$ & 0.48 & 0.48 & 0.68 & 0.27 & 0.27 & 0.39 \\
\hline $\mathrm{CD}(\mathrm{p}=0.05)$ & NS & 1.51 & NS & NS & NS & NS \\
\hline
\end{tabular}

$\mathrm{D}_{1}=$ Last week of June; $\mathrm{D}_{2}=$ First week of July 
Table 2. Population dynamics of spiders during September, 2011 and 2012.

\begin{tabular}{|c|c|c|c|c|c|c|}
\hline \multicolumn{7}{|c|}{ Monthly mean population of spiders / 10 hills } \\
\hline \multirow{3}{*}{ Varieties } & \multicolumn{3}{|c|}{2011} & \multicolumn{3}{|c|}{2012} \\
\hline & \multicolumn{2}{|c|}{ Dates of transplanting } & \multirow[t]{2}{*}{ Mean } & \multicolumn{2}{|c|}{ Dates of transplanting } & \multirow[t]{2}{*}{ Mean } \\
\hline & D1 & D2 & & D1 & D2 & \\
\hline CSR 30 & 16.28 & 12.44 & 14.36 & 11.00 & 16.35 & 13.67 \\
\hline PR 114 & 12.28 & 16.56 & 14.42 & 18.60 & 24.70 & 21.65 \\
\hline \multirow[t]{2}{*}{ Mean } & 14.28 & 14.50 & & 14.80 & 20.52 & \\
\hline & Variety & Date & Variety $\times$ Date & Variety & Date & Variety $\times$ Date \\
\hline $\mathrm{SE}(\mathrm{m})$ & 0.97 & 0.97 & 1.38 & 0.62 & 0.62 & 0.88 \\
\hline $\mathrm{CD}(\mathrm{p}=0.05)$ & NS & NS & 4.28 & 1.94 & 1.94 & NS \\
\hline
\end{tabular}

$D_{1}=$ Last week of June; $D_{2}=$ First week of July

Table 3. Population dynamics of spiders during October, 2011 and 2012.

\begin{tabular}{|c|c|c|c|c|c|c|}
\hline \multicolumn{7}{|c|}{ Monthly mean population of spiders / 10 hills } \\
\hline \multirow{3}{*}{ Varieties } & \multicolumn{3}{|c|}{2011} & \multicolumn{3}{|c|}{2012} \\
\hline & \multicolumn{2}{|c|}{ Dates of transplanting } & \multirow[t]{2}{*}{ Mean } & \multicolumn{2}{|c|}{ Dates of transplanting } & \multirow[t]{2}{*}{ Mean } \\
\hline & D1 & D2 & & D1 & D2 & \\
\hline CSR 30 & 16.26 & 19.00 & 17.63 & 15.50 & 18.40 & 16.95 \\
\hline PR 114 & 22.60 & 21.90 & 22.25 & 28.30 & 27.00 & 27.65 \\
\hline \multirow[t]{2}{*}{ Mean } & 19.43 & 20.45 & & 21.90 & 22.70 & \\
\hline & Variety & Date & Variety $\times$ Date & Variety & Date & Variety $\times$ Date \\
\hline $\mathrm{SE}(\mathrm{m})$ & 0.89 & 0.89 & 1.25 & 1.18 & 1.18 & 1.68 \\
\hline $\mathrm{CD}(\mathrm{p}=0.05)$ & 2.75 & NS & NS & 3.69 & NS & NS \\
\hline
\end{tabular}

$\mathrm{D}_{1}=$ Last week of June; $\mathrm{D}_{2}=$ First week of July

Table 4. Population dynamics of mirid bugs during September, 2011 and 2012.

\begin{tabular}{|c|c|c|c|c|c|c|}
\hline \multicolumn{7}{|c|}{ Monthly mean population of mirid bug / 10 hills } \\
\hline \multirow{3}{*}{ Varieties } & \multicolumn{3}{|c|}{2011} & \multicolumn{3}{|c|}{2012} \\
\hline & \multicolumn{2}{|c|}{ Dates of transplanting } & \multirow[t]{2}{*}{ Mean } & \multicolumn{2}{|c|}{ Dates of transplanting } & \multirow[t]{2}{*}{ Mean } \\
\hline & D1 & D2 & & D1 & D2 & \\
\hline CSR 30 & 18.04 & 7.60 & 12.82 & 1.20 & 2.35 & 1.77 \\
\hline PR 114 & 4.52 & 4.40 & 4.46 & 1.75 & 2.95 & 2.35 \\
\hline \multirow[t]{2}{*}{ Mean } & 11.28 & 6.00 & & 1.47 & 2.65 & \\
\hline & Variety & Date & Variety $\times$ Date & Variety & Date & Variety $\times$ Date \\
\hline $\mathrm{SE}(\mathrm{m})$ & 1.14 & 1.14 & 1.61 & 0.17 & 0.17 & 0.25 \\
\hline $\mathrm{CD}(\mathrm{p}=0.05)$ & 3.55 & 3.55 & 5.02 & 0.54 & 0.54 & NS \\
\hline
\end{tabular}

$\mathrm{D}_{1}=$ Last week of June; $\mathrm{D}_{2}=$ First week of July

seasons. The population (22.25 and 27.65/10 hills) of spiders on variety PR 114 was significantly higher than its population (17.63 and 16.95/10 hills) on CSR 30 during 2011 and 2012, respectively. The interaction between dates and varieties was non-significant during the both years.

Population dynamics of mirid bugs during August 2011 and 2012: Mirid bugs did not appear in any sampling period during the month of August, 2011 and 2012.
Population dynamics of mirid bugs during September 2011 and 2012: The mean population (Table 4) of mirid bugs differed significantly between two varieties in September, 2011. A significantly $(p=0.05)$ higher population (12.82 bugs/10 hills) was recorded on the variety CSR 30 than on the variety PR 114 (4.46 bugs/10 hills). However, a reverse trend was observed with the test varieties and dates during 2012.The population of mirid bugs also differed significantly in two dates. The mean population (11.28/10 hills) of 
Table 5. Population dynamics of mirid bugs during October, 2011 and 2012.

Monthly mean population of mirid bug / 10 hills

2011

2012

\begin{tabular}{|c|c|c|c|c|c|c|}
\hline \multirow[t]{2}{*}{ Varieties } & \multicolumn{2}{|c|}{ Dates of transplanting } & \multirow[t]{2}{*}{ Mean } & \multicolumn{2}{|c|}{ Dates of transplanting } & \multirow[t]{2}{*}{ Mean } \\
\hline & D1 & D2 & & D1 & D2 & \\
\hline CSR 30 & 31.33 & 40.33 & 35.83 & 38.50 & 28.60 & 33.55 \\
\hline PR 114 & 13.60 & 14.70 & 14.15 & 53.70 & 60.10 & 56.90 \\
\hline Mean & 22.46 & 27.51 & & 46.10 & 44.35 & \\
\hline & Variety & Date & Variety $\times$ Date & Variety & Date & Variety $\times$ Date \\
\hline $\mathrm{SE}(\mathrm{m})$ & 1.74 & 1.74 & 2.46 & 2.86 & 2.86 & 4.04 \\
\hline $\mathrm{CD}(\mathrm{p}=0.05)$ & 5.41 & NS & NS & 8.90 & NS & NS \\
\hline
\end{tabular}

$\mathrm{D}_{1}=$ Last week of June; $\mathrm{D}_{2}=$ First week of July

Table 6. Population dynamics of coccinellid, carabid and staphylinid beetles during August, 2011 and 2012.

\begin{tabular}{|c|c|c|c|c|c|c|}
\hline \multicolumn{7}{|c|}{ Monthly mean population of coccinellids / 10 hills } \\
\hline \multirow{3}{*}{ Varieties } & \multicolumn{3}{|c|}{2011} & \multicolumn{3}{|c|}{2012} \\
\hline & \multicolumn{2}{|c|}{ Dates of transplanting } & \multirow[t]{2}{*}{ Mean } & \multicolumn{2}{|c|}{ Dates of transplanting } & \multirow[t]{2}{*}{ Mean } \\
\hline & D1 & D2 & & D1 & D2 & \\
\hline CSR 30 & 0.35 & 0.15 & 0.25 & 0.10 & 0.10 & 0.10 \\
\hline PR 114 & 0.15 & 0.15 & 0.15 & 0.00 & 0.00 & 0.00 \\
\hline \multirow[t]{2}{*}{ Mean } & 0.25 & 0.15 & & 0.05 & 0.05 & \\
\hline & Variety & Date & Variety $\times$ Date & Variety & Date & Variety $\times$ Date \\
\hline $\mathrm{SE}(\mathrm{m})$ & 0.08 & 0.08 & 0.18 & 0.05 & 0.05 & 0.07 \\
\hline $\mathrm{CD}(\mathrm{p}=0.05)$ & NS & NS & NS & NS & NS & NS \\
\hline
\end{tabular}

$D_{1}=$ Last week of June; $D_{2}=$ First week of July

Table 7. Population dynamics of coccinellid, carabid and staphylinid beetles during September, 2011 and 2012.

\begin{tabular}{|c|c|c|c|c|c|c|}
\hline \multicolumn{7}{|c|}{ Monthly mean population of coccinellids / 10 hills } \\
\hline \multirow{3}{*}{ Varieties } & \multicolumn{3}{|c|}{2011} & \multicolumn{3}{|c|}{2012} \\
\hline & \multicolumn{2}{|c|}{ Dates of transplanting } & \multirow[t]{2}{*}{ Mean } & \multicolumn{2}{|c|}{ Dates of transplanting } & \multirow[t]{2}{*}{ Mean } \\
\hline & D1 & D2 & & D1 & D2 & \\
\hline CSR 30 & 0.33 & 0.32 & 0.32 & 0.05 & 1.05 & 0.55 \\
\hline PR 114 & 0.44 & 0.16 & 0.30 & 0.80 & 1.65 & 1.22 \\
\hline \multirow[t]{2}{*}{ Mean } & 0.38 & 0.24 & & 0.42 & 1.35 & \\
\hline & Variety & Date & Variety $\times$ Date & Variety & Date & Variety $\times$ Date \\
\hline $\mathrm{SE}(\mathrm{m})$ & 0.13 & 0.13 & 0.18 & 0.13 & 0.13 & 0.19 \\
\hline $\mathrm{CD}(\mathrm{p}=0.05)$ & NS & NS & NS & 0.41 & 0.41 & NS \\
\hline
\end{tabular}

$\mathrm{D}_{1}=$ Last week of June; $\mathrm{D}_{2}=$ First week of July

mirid bugs was significantly higher in $\mathrm{D}_{1}$ than $\mathrm{D}_{2}$ (6.0/10 hills).

The number of mirid bugs (2.35/10 hills) on PR 114 was significantly higher than the numbers $(1.77 / 10$ hills) on CSR 30. Similarly, 2.65 mirid bugs/10 hills in $\mathrm{D}_{2}$ were significantly $(\mathrm{p}=0.05)$ higher than 1.47 mirids/10 hills in $D_{1}$. The interaction between varieties and date of transplanting was found significant ( $p=0.05$ ) with respect to mirid bug population during 2011 but non-significant differences were observed during 2012. The population of mirids in variety CSR
30 was 18.04/10 hills and 7.6/10 hills in June and July transplanting during 2011.

Population dynamics of mirid bugs during October 2011 and 2012: The data on population of mirid bugs sampled during October are presented in table 5. The data revealed that the population of mirid bugs (35.83/10 hills) on the variety CSR 30 was more as compared to 14.15 mirid bugs/10 hills on the variety PR 114 during 2011. The trend in population build up of mirid bugs reversed during 2012. The population of mirid bugs $(56.90 / 10$ hills) was significantly $(p=0.05)$ 
Table 8. Population dynamics of coccinellid, carabid and staphylinid beetles during October, 2011 and 2012.

\begin{tabular}{|c|c|c|c|c|c|c|}
\hline \multicolumn{7}{|c|}{ Monthly mean population of coccinellids / 10 hills } \\
\hline & & 2011 & & & 2012 & \\
\hline \multirow[t]{2}{*}{ Varieties } & \multicolumn{2}{|c|}{ Dates of transplanting } & \multirow[t]{2}{*}{ Mean } & \multicolumn{2}{|c|}{ Dates of transplanting } & \multirow[t]{2}{*}{ Mean } \\
\hline & D1 & D2 & & D1 & D2 & \\
\hline CSR 30 & 0.66 & 7.46 & 5.06 & 6.80 & 12.50 & 9.65 \\
\hline PR 114 & 0.60 & 0.00 & 0.30 & 14.20 & 8.70 & 11.45 \\
\hline \multirow[t]{2}{*}{ Mean } & 1.67 & 3.73 & & 10.50 & 10.60 & \\
\hline & Variety & Date & Variety $\times$ Date & Variety & Date & Variety $\times$ Date \\
\hline $\mathrm{SE}(\mathrm{m})$ & 0.44 & 0.44 & 0.62 & 0.75 & 0.75 & 1.05 \\
\hline $\mathrm{CD}(\mathrm{p}=0.05)$ & 1.36 & 1.36 & 1.92 & NS & NS & 3.28 \\
\hline
\end{tabular}

$\mathrm{D}_{1}=$ Last week of June; $\mathrm{D}_{2}=$ First week of July

Table 9. Population dynamics of nymphal and adult parasitoids during August, 2011 and 2012.

\begin{tabular}{lcccccc}
\hline \multicolumn{5}{c}{ Monthly mean population of parasitoids / 10 hills } \\
\hline \multirow{3}{*}{ Varieties } & \multicolumn{7}{c}{$\mathbf{2 0 1 1}$} & \multicolumn{2}{c}{$\mathbf{2 0 1 2}$} \\
\cline { 2 - 7 } & \multicolumn{7}{c}{ Dates of transplanting } & Mean & Dates of transplanting & Mean \\
\cline { 2 - 7 } CSR 30 & D1 & D2 & & D1 & D2 & 0.06 \\
PR 114 & 0.20 & 0.05 & 0.12 & 0.15 & 0.00 & 0.15 \\
\hline Mean & 0.00 & 0.05 & 0.02 & 0.10 & 0.20 & Variety $\times$ Date \\
\hline & 0.10 & 0.05 & & 0.12 & 0.10 & 0.11 \\
\hline SE (m) & Variety & Date & Variety $\times$ Date & Variety & Date & NS \\
CD (p=0.05) & 0.04 & 0.04 & 0.06 & 0.08 & 0.08 & NS \\
\hline
\end{tabular}

$\mathrm{D}_{1}=$ Last week of June; $\mathrm{D}_{2}=$ First week of July

Table 10. Population dynamics of nymphal and adult parasitoids during September, 2011 and 2012.

\begin{tabular}{|c|c|c|c|c|c|c|}
\hline \multicolumn{7}{|c|}{ Monthly mean population of parasitoids / 10 hills } \\
\hline \multirow{3}{*}{ Varieties } & \multicolumn{3}{|c|}{2011} & \multicolumn{3}{|c|}{2012} \\
\hline & \multicolumn{2}{|c|}{ Dates of transplanting } & \multirow[t]{2}{*}{ Mean } & \multicolumn{2}{|c|}{ Dates of transplanting } & \multirow[t]{2}{*}{ Mean } \\
\hline & D1 & D2 & & D1 & D2 & \\
\hline CSR 30 & 1.08 & 1.00 & 1.04 & 0.50 & 1.35 & 0.92 \\
\hline PR 114 & 1.12 & 0.72 & 0.92 & 1.40 & 1.60 & 1.50 \\
\hline Mean & 1.10 & 0.86 & & 0.95 & 1.47 & \\
\hline & Variety & Date & Variety $\times$ Date & Variety & Date & Variety $\times$ Date \\
\hline $\mathrm{SE}(\mathrm{m})$ & 0.17 & 0.17 & 0.24 & 0.23 & 0.23 & 0.33 \\
\hline $\mathrm{CD}(\mathrm{p}=0.05)$ & NS & NS & NS & NS & NS & NS \\
\hline
\end{tabular}

$\mathrm{D}_{1}=$ Last week of June; $\mathrm{D}_{2}=$ First week of July

higher on variety PR 114 than 33.55 mirid bugs/10 hills on CSR 30. However, the population in two dates was on par during 2011 and 2012. Also the interaction was non-significant during both the years.

Population dynamics of beetles during August 2011 and 2012: The data on combined population of coccinelid, carabid and staphylinid beetles remained very low throughout the season on both the varieties in the month of August during 2011 and 2012. The population was on par with respect to varieties and dates. The interaction was also non-significant $(\mathrm{p}=0.05)$ during both the years (Table 6).
Population dynamics of beetles during September 2011 and 2012: The population of coccinellid, carabid and staphylinid beetles did not build up much in September, 2011. The population was on par with respect to varieties and dates. However, the population of these predators differed significantly between varieties and dates during 2012. The interaction was also non-significant during both the years. The population of these predators was slightly more in 2012 as compared to 2011 (Table 7).

Population dynamics of beetles during October, 2011 and 2012: The data presented in table 8 revealed 
Table 11. Population dynamics of nymphal and adult parasitoids during October, 2011 and 2012.

\begin{tabular}{lcccccc}
\hline & \multicolumn{5}{c}{ Monthly mean population of parasitoids / 10 hills } \\
\hline \multirow{3}{*}{ Varieties } & \multicolumn{7}{c}{$\mathbf{2 0 1 1}$} & \multicolumn{4}{c}{$\mathbf{2 0 1 2}$} \\
\cline { 2 - 7 } & \multicolumn{2}{c}{ Dates of transplanting } & Mean & Dates of transplanting & Mean \\
\cline { 2 - 7 } & D1 & D2 & & 5.55 & 4.90 & 5.22 \\
CSR 30 & 0.26 & 0.13 & 0.20 & 6.00 & 5.90 & 5.95 \\
PR 114 & 1.00 & 0.30 & 0.65 & 5.77 & 5.40 & \\
Mean & 0.63 & 0.21 & & Variety & Date & Variety $\times$ Date \\
\hline & Variety & Date & Variety $\times$ Date & 0.64 & 0.64 & 0.91 \\
SE (m) & 0.14 & 0.14 & 0.20 & NS & NS & NS \\
\hline
\end{tabular}

$\mathrm{D}_{1}=$ Last week of June; $\mathrm{D}_{2}=$ First week of July

that the population of the predators was significantly $(\mathrm{p}=0.05)$ more $(5.07 / 10$ hills) on variety CSR 30 than PR 114 (0.30/10 hills). The population in two dates also differed significantly $(\mathrm{p}=0.05)$ and was higher (3.73/10 hills) in $\mathrm{D}_{2}$ during 2011 . The population of these predators was non-significant during October, 2012 in both with respect to varieties and dates of transplanting. The interaction between varieties and dates was significant.

Population dynamics of nymphal and adult parasitoids, during 2011 and 2012: The population of nymphl-adult parasitoids remained very low throughout the crop seasons during both the years. The population of parasitoids did not differ significantly with respect to varieties and dates of transplanting throughout the study period (August to October, 2011 and 2012) except a higher parasitoids population of $0.65 / 10$ hills on PR 114 as compared to CSR 30 (Tables 9, 10 and 11).

\section{DISCUSSION}

Effect of varieties and dates of transplanting on pest and natural enemies has been reported by a few workers from different agro-climatic zones which differ in cropping patterns, varietal spectrum, cultural practices and weather. The present findings can not be compared with most of the earlier workers because of the different sets of conditions, especially the differences in date of transplanting. Further, the search of literature revealed a few references on this aspect. The conclusions of their studies have been given here. Karuppuchamy and Gopalan (1986) reported that the effect of the time of planting on the incidence of insect pests on rice was investigated in the field in Tamil Nadu. During the kuruvai and samba seasons, populations of the green leafhopper, Nephotettix sp. and $N$. lugens were greatest on rice planted on $16^{\text {th }}$ August. During thaladi, the population of Nephotettix $s p$. was greatest on the crop planted on $7^{\text {th }}$ November which showed that the population fluctuation of green leafhopper depends on the climatic conditions as well as the time of planting. These results support the present findings. The incidence of stem borer Chilo suppressalis was highest in the thaladi season on the crop planted on $16^{\text {th }}$ September. The optimum times for planting were found to be the $1^{\text {st }}$ week of August, $1^{\text {st }}$ week of October and $3^{\text {rd }}$ week of October for the kuruvai, samba and thaladi seasons, respectively. Magunmder et al. (2013) also supported the present findings who reported that the rice planting on $1^{\text {st }}$ July resulted in lower GLH, BPH and WLH incidence than on $16^{\text {th }}$ July, $1^{\text {st }}$ and $16^{\text {th }}$ August. Likewise, the abundance of natural enemies was high during early season and decline thereafter. The population densities of $N$. lugens, S. furcifera (WBPH), Laodelphax striatellus (SBPH), Nephotettix cincticeps (GRLH), Chlorops oryzae (RSM), C. suppressalis (SRB) and C. medinalis (RLF) were affected more by transplanting time than fertilizer levels. The later transplanting time induced the higher population densities of BPH, WBPH, SBPH, GRLH, RSM, whereas SRB and RLF were affected by earlier transplanting times in rice fields (Ma and Lee, 1996).

\section{Conclusion}

The mean population of spiders appeared in August during both the years and significantly $(\mathrm{p}=0.05)$ higher on variety PR 114 planted in July $\left(\mathrm{D}_{2}\right)$. However, the population of mirid bugs appeared during September and significantly higher on variety CSR 30 planted in June $\left(D_{1}\right)$ and the trend was reverse during 2012. The mean population of coccinelid, carabid and staphylinid beetles remained very low throughout the season on both the varieties in the month of August during 2011 and 2012. However, the population of these predators was influenced significantly by the varieties and dates during September and October whereas the population of coleopterans was significantly higher on variety CSR 30 and in $\mathrm{D}_{2}$ than on PR 114 and in $\mathrm{D}_{1}$ during 2011. The population of nymphal-adult parasitoids remained very low during 2011 and 2012 and was not influenced by varieties and dates.

\section{ACKNOWLEDGEMENT}

The authors are grateful to CCS Haryana Agricultural University, Hisar, for the permission granted to publish the material, which is a part of the thesis submitted by the first author for the award of Ph. D. (Agri.) degree. 
Thanks are also due to Rice Research Station, Kaul (Kaithal) for providing necessary facilities during my research work.

\section{REFERENCES}

Anonymous (2008). Progress Report, Entomology and Plant Pathology, All India Coordinated Rice Improvement Programme, DRR, ICAR, Rajendranagar, Hyderabad, Andra Pradesh, India.

Anonymous (2010). Progress Report, Entomology and Plant Pathology, All India Coordinated Rice Improvement Programme, DRR, ICAR, Rajendranagar, Hyderabad, Andra Pradesh, India.

Anonymous (2012). Ministry of Agriculture, Govt. of India. www.indiastat.com.

Claridge, M. F., Morgan, J. C., Steenkiste, A. E., Iman, M. and Damayanti, D. (1999). Seasonal patterns of egg parasitism and natural biological control of rice brown planthopper in Indonesia. Agricultural and Forest Entomology, 1: 297-304.

Dupo, A. L. B., and Barrion, A. T. (2009). Taxonomy and general biology of Delphacid planthopper in rice agrosystems. Planthoppers: New threats to the sustainability of intensive rice production system in Asia. IRRI, Los Barros, Philippines, 460 p.

FAO (2009). FAO STAT database Food and Agriculture Organization, Rome. www.faostat.org.

Heinrichs, E. A. and Mochida, O.. (1984). From secondary to major pest status: the case of insecticide induced rice brown plant hopper, Nilaparvata lugens resurgence.
Protection Ecology, 7: 201-218.

Karuppuchamy, P. and Gopalan, M. (1986). Influence of time of planting on the incidence of rice pests. Madras Agricultural Journal, 73: 606-609.

Kenmore, P.E., Carino, F.O., Perez, C.A., Dyck, V.A. and Gutierrez, A.P. (1984). Population Regulation of the Rice brown plant hopper with in Rice Fields in the Philippines, pp. 32-35.

Krishnaiah, N. V., Lakshmi, V. J., Pasalu, I. C., Katti, G. R. and Padmavathi, C. (2008). Insecticides in Rice- IPM, Past, Present and Future, Directorate of Rice Research, ICAR, Hyderabad, India, 148 p.

Ma, K. C. and Lee, S. C. (1996). Occurrence of major rice insect pests at different transplanting times and fertilizer levels in paddy field. Korean Journal of Applied Entomology, 35: 132-136.

Magunmder, S. K.G., Ali, M. P., Choudhury, T. R. and Rahin, S. A. (2013). Effect of variety and transplanting date on the incidence of insect pests and their natural enemies. World Journal of Agricultural Sciences, 1: 158-167.

Prashant, T., Shivashankar, M., Chandrashekharaiah and Naveena, N.L. (2012). Seasonal incidence of brown planthopper, $N$. lugens and its predators in Chamarajanagar, Karnataka, India. Bioinfolet, 9: 454456.

Singh, J. and Dhaliwal, G.S. (1994). Insect Pest Management in Rice: A perspective. Trends In: Agriculture Insect Pest Management. Commonwealth Publishers, New Delhi, pp. 56-112. 